\title{
IMMUNOHISTOCHEMICAL ANALYSIS FOR CD21, CD35, CALDESMON AND S100 PROTEIN ON DENDRITIC CELLS TYPES IN ORAL LYMPHOMAS
}

\author{
Ricardo Alves MESQUITA ${ }^{1}$, Vera Cavalcanti de ARAÚJO², Roberto Antônio Pinto PAES ${ }^{3}$, \\ Fábio Daumas NUNES ${ }^{4}$, Suzana Cantanhede Orsini Machado de SOUSA ${ }^{5}$
}

1- DDS, MSc, PhD, Adjunct Professor, Department of Oral Surgery, Oral Medicine and Oral Pathology, Dental School, Federal University of Minas Gerais, Belo Horizonte, MG, Brazil.

2- DDS, MSc, PhD, Full Professor, Department of Oral Pathology, School and Research Center of Dentistry "São Leopoldo Mandic", Campinas, SP, Brazil.

3- MD, MSc, PhD, Assistant Professor, Department of Pathological Anatomy, Hospital of Santa Casa of São Paulo, São Paulo, SP, Brazil.

4- DDS, MSc, PhD, Associate Professor, Department of Oral Pathology, Dental School, University of Sao Paulo, São Paulo, SP, Brazil.

5- DDS, MSc, PhD, Full Professor, Department of Oral Pathology, Dental School, University of Sao Paulo, São Paulo, SP, Brazil.

Corresponding address: Ricardo Alves Mesquita, DDS, PhD - Universidade Federal de Minas Gerais - Faculdade de Odontologia - Disciplina de Patologia Bucal, sala 3204 - Av. Antônio Carlos, 6627 Pampulha - 31.270-901 - Belo Horizonte, MG - Brasil - Phone: $55313409-2478$ - Fax: 5531 3409-2472

e-mail: ramesquita@ufmg.br

Received: May 6, 2008 - Modification: October 9, 2008 - Accepted: November 9, 2008

\begin{abstract}
$O$

bjective: Follicular dendritic cells (FDCs) and interdigitating dendritic cells (IDCs) are dendritic cells found in lymphoid follicles, reactive follicles and in lymphomas. The goal of this study was to evaluate the presence and distribution of FDCs and IDCs in oral lymphomas. Material and Methods: Immunohistochemistry reactions were applied to 50 oral lymphomas using the antibodies anti-CD21, anti-CD35 and anti-caldesmon to FDCs, and anti-S100 protein to IDCs. Caldesmon+/FDCs and S100+/IDCs were quantified in Imagelab ${ }^{\circledR}$ software. Results: FDCs revealed by CD21 and CD35 were positively stained in two cases of diffuse large B-cell lymphoma, one MALT lymphoma, and in one case of mantle cell lymphoma. FDCs were immunopositive to caldesmon in all cases, as well as IDCs to S100 protein. Burkitt lymphoma presented a lower amount of caldesmon+/FDCs and S100+/IDCs than diffuse large B-cell lymphoma and plasmablastic lymphoma of the oral mucosa type. Conclusions: The microenvironment determined by neoplastic lymphoid cells in oral lymphomas is responsible by the development and expression of dendritic cells types.
\end{abstract}

Key words: CD21. CD35. Follicular dendritic cells. Interdigitating dendritic cells. Immunohistochemistry. Lymphoma. Oral lymphomas.

\section{INTRODUCTION}

Dendritic cells (DCs) are non-lymphoid antigenpresenting cells distributed widely throughout the body and are distinguishable from macrophages by their lack of both phagocytic activity and capacity to act as effectors cells. Morphologically, they present a complex of dendritic cytoplasmic projections, one or more lobulated nucleoli, clear cytoplasm with scattered organelles and lack of both phagocytic activity and capacity to act as effectors cells. DCs are classified into two groups: B- and T-cells associated DCs. Follicular dendritic cells (FDCs) represent B-cell associated DCs. T-cell associated DCs include the interdigitating dendritic cells (IDCs), indeterminate cells, Langerhans cells, connective tissue dendritic cells and veiled cells (dendritic leukocytes) ) $^{9,22,23}$.
FDCs are located in B-cell dependent areas of the lymphoid follicles of secondary lymphoid organs. FDCs form a three-dimensional meshwork in these B-cell areas. Functionally, they have an ability to bind and retain antigens through linking complement and immune complexes for a long time, and are involved in B-cell proliferation, selection and differentiation ${ }^{18,21}$. FDCs can be stained through the complement receptors, $\mathrm{C} 3 \mathrm{~d}(\mathrm{CD} 21)$ and $\mathrm{C} 3 \mathrm{~b}(\mathrm{CD} 35)$, and by the low affinity to IgE receptor (CD23). Also, FDCs are immunopositive to cell cycle markers, FDCs-associated antigen (DCR-1; Ki-M4; CNA.42; DR53), intermediated filament, adhesion molecules, cytokine receptors and to calcium-bindings proteins (calmodulin; caldesmon; annexin II; annexin VI and S100 protein $\alpha$-subunit). The immunophenotype, as well as ultrastructural features, of FDCs are variable depending on their distribution in the 
zones of lymphoid follicles. There are few effective antibodies to identify FDCs in routinely processed paraffin sections ${ }^{6,8,9,15}$.

IDCs are located in the T-cell areas of lymph node, spleen, and thymus, and are related to the function of presenting antigens to T-cells. IDCs may be detectable by CD45, class II MHC, and S100 protein ${ }^{2,25}$. In contrast to Langerhans cells, IDCs are immunonegative to CD1 $\mathrm{a}^{5,20}$.

Due to the relationship between FDCs/B-cell and IDCs/ T-cell, the microenvironment of the neoplastic or reactive transformation of B- and T-cell produce alterations in expression of dendritic cells types. Also, a comprehensive investigation on this subject might provide valuable information about diagnosis of lymphomas ${ }^{1,3,7,12,14,17,24}$. Up to now, there are no studies of DCs in oral lymphomas. The goal of this study was to evaluate the presence and distribution of FDCs and IDCs in oral lymphomas. Also, quantitative analysis of caldesmon+/FDCs and S100+/IDCs was performed.

\section{MATERIAL AND METHODS}

The experimental protocol was approved by the Committee of Bioethics in Research of the Dental School of the University of São Paulo, São Paulo, SP, Brazil (number 150/00).

\section{Tissue Samples}

Routinely processed paraffin sections from 50 oral lymphomas were selected from the files of the Oral Pathology Service at the University of Sao Paulo, Brazil. Oral lymphomas were classified according to the World Health Organization classification $/ 2001^{10}$ and Colomo, et al. ${ }^{4}$ by morphology, immunophenotype, Epstein Barr Virus detection and $\operatorname{IgH}$ gene rearrangement. Representative samples were diffuse large B-cell lymphoma (DLBCL, $\mathrm{N}=17$ ); plasmablastic lymphoma of the oral mucosa type (PBLOMT, $\mathrm{N}=11$ ); Burkitt lymphoma (BL, $\mathrm{N}=15)$; extranodal marginal zone B-cell lymphoma of mucosaassociated lymphoid tissue (MALT lymphoma, $\mathrm{N}=2$ ); mantle cell lymphoma (MCL, $\mathrm{N}=1$ ); extranodal NK/T-cell lymphoma, nasal type (ETCL, $\mathrm{N}=3$ ), and peripheral T-cell lymphoma, unspecified (PTCL, $\mathrm{N}=1$ ). All cases were primary of the oral cavity, since physical exam did not demonstrate signals of disease in other regions of the body.

\section{Immunohistochemistry and Quantitative Analysis}

FDCs were characterized with the antibodies anti-CD21, anti-CD35, and anti-caldesmon. Since caldesmon is also expressed in the vessel walls, consecutive sections were also stained with anti-CD34 and both stain were submitted to quantification with the use of a computerized system (Imagelab ${ }^{\circledR}$ Software, LIDO, FOUSP, Brazil). Five fields of each section were selected in a light microscope (Laborlux; Leitz, Wetzlar, Germany) at 100x magnification. Images were transferred to a computer monitor with area of $640 \times 480$ pixels, and the quantification was performed by subtraction of images. The values of the caldesmon+/FDCs were obtained through the total of caldesmon+/ immunoexpression minus CD34+/immunoexpression and expressed in $\mu \mathrm{m}^{2}$. IDCs were identified by the antibody antiS100 protein. Since Langerhans cells also express S100 protein, antibody anti-CD1a was also used in consecutive sections to exclude the Langerhans cells. S100+/IDCs were counted in the light microscope (Laborlux; Leitz, 400X magnification). Ten fields were selected for each case using an integration reticule and values expressed in $\mathrm{mm}^{2}$. The statistical analysis was considered only in the DLBCL, PBLOMT and BL, because the sample of these cases was sufficient to statistical analysis. This analysis was performed with Mann-Whitney test and significance statistical was evaluated at 0.05 level.

A universal automatic system of staining (Dako Auto Staining $^{\circledR}$, Dako Corporation, Carpinteria, CA, USA) was used for immunohistochemistry reactions with the strepatavidin-biotin standard protocol in 3- $\mu \mathrm{m}$-thick sections. The primary antibodies used were: CD21 (DAKO ${ }^{\circledR}$, clone $1 \mathrm{~F} 8,1: 50$, incubation for $40 \mathrm{~min}$ at $37^{\circ} \mathrm{C}$ ), CD35 $\left(\mathrm{DAKO}^{\circledR}\right.$, clone Ber-MAC-CDR, 1:20, incubation for 40 min at $37^{\circ} \mathrm{C}$ ), caldesmon (Novocastra ${ }^{\circledR}$, clone TD107, 1:50, incubation for $30 \mathrm{~min}$ at $37^{\circ} \mathrm{C}$ ), CD1a (Serotec ${ }^{\circledR}$, clone 010 , incubation for $30 \mathrm{~min}$ at $\left.37^{\circ} \mathrm{C}\right), \mathrm{S} 100$ protein $\left(\mathrm{DAKO}^{\circledR}\right.$, clone Z0311, incubation for $30 \mathrm{~min}$ at $37^{\circ} \mathrm{C}$ ), and $\mathrm{CD} 34$ (Novocastra $^{\circledR}$, clone QBEnd/10, 1:50, incubation for $30 \mathrm{~min}$ at $37^{\circ} \mathrm{C}$ ). The sections were submitted to antigen retrieval. Sections for the reactions with CD21 and CD35 were immersed in target retrieval solution pH $6.0\left(\mathrm{DAKO}^{\circledR}\right.$, $\mathrm{S} 1700$ ) heated to $95^{\circ} \mathrm{C}$ for $30 \mathrm{~min}$. To caldesmon, CD1a, and CD34, the sections were immersed in citric acid (SIGMA ${ }^{\circledR}$ CHEMICAL CO., St. Louis, MO, USA) buffer $0.01 \mathrm{M}, \mathrm{pH} 6.0$ and heated to $95^{\circ} \mathrm{C}$ for $30 \mathrm{~min}$. Sections for the reaction with $\mathrm{S} 100$ protein were not submitted to antigen retrieval. Appropriate positive and negative controls were used.

\section{RESULTS}

The pattern of expression of CD21 and CD35 was the same. CD21 and CD35 positively stained FDCs in four cases of oral lymphomas: (a) two cases of DLBCL, (b) one MALT lymphoma, and (c) on the case of MCL. In the DLBCL, immunoexpression was observed in pseudofollicular proliferation centers ${ }^{14,17}$. The pattern was a sparse and disrupted meshwork (Figures 1A and 1B). MALT lymphoma presented FDCs as a dense and confluent meshwork corresponding to colonized follicles (Figures $1 \mathrm{C}$ and 1D). MCL presented the distribution of FDCs as a loosely arranged, ill-defined and expanded meshwork (Figures 1E and $1 \mathrm{~F})$.

Caldesmon+/FDCs were present in all oral lymphomas and appeared as a dense and confluent meshwork (lacy pattern) among the neoplastic lymphoid cells (Figure 1G). In cases immunopositive to CD21 and CD35, caldesmon+/ FDCs were coincident with CD21 and CD35 stain. CD34 

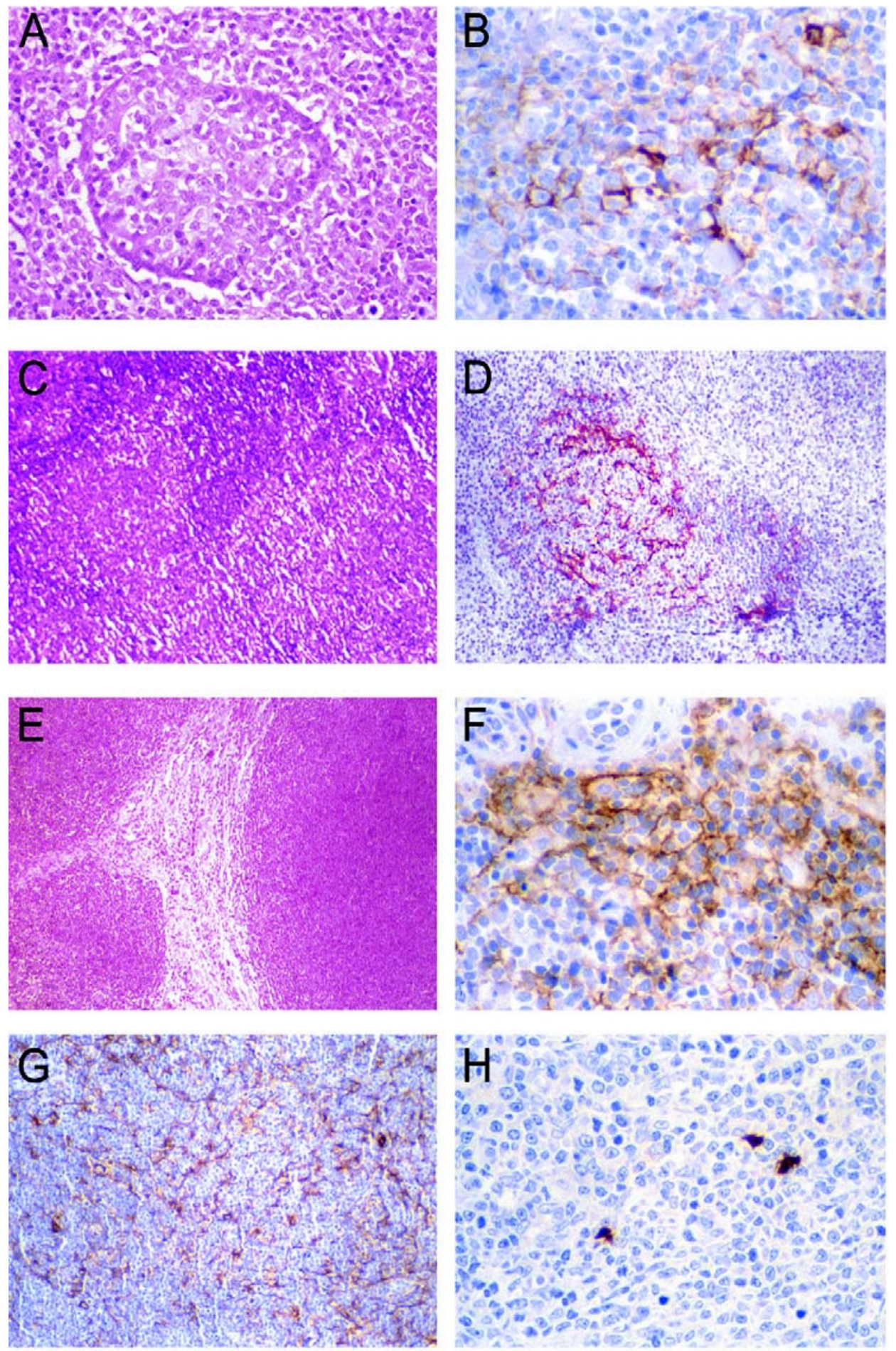

FIGURE 1- A- Pseudofollicular proliferation center in the diffuse large B-cell lymphoma (Hematoxylin-eosin, original magnification x320). B- Follicular dendritic cells stained by CD21 presented as sparse, disrupted meshwork between lymphoid cells of the pseudofollicular proliferation center of the diffuse large B-cell lymphoma (streptavidin-biotin, original magnification x640). CMALT Iymphoma presenting reactive follicles (Hematoxylin-eosin, original magnification $\times 100$ ). D- Colonized follicles by follicular dendritic cells. A meshwork is revealed by CD21 in the MALT lymphoma (streptavidin-biotin, original magnification x320). EMantle cell lymphoma demonstrates a monomorphic lymphoid proliferation with a nodular pattern (Hematoxylin-eosin, original magnification x100). F- CD21 demonstrates loosely arranged, ill-defined and expanded meshwork of follicular dendritic cells at the periphery of the mantle cell lymphoma (streptavidin-biotin, original magnification x640). G- Caldesmon revealed a dense and confluent meshwork of the follicular dendritic cells among lymphoid cells of in a case of diffuse large B-cell lymphoma (streptavidin-biotin, original magnification $\mathrm{x200}$ ). $\mathrm{H}$ - Interdigitating dendritic cells revealed by S100 protein in one case of the diffuse large B-cell lymphoma are visualized as irregular spots (streptavidin-biotin, original magnification $\times 320$ ) 
TABLE 1- Mean values and standard deviation (SD) of the quantification of caldesmon+/follicular dendritic cells (FDCs) and S100+/interdigitating dendritic cells (IDCs). P values to caldesmon+/FDCs between $\left(^{*}\right)$ diffuse large B-cell lymphoma and Burkitt lymphoma, $\left.{ }^{* \star}\right)$ plasmablastic lymphoma of the oral mucosa type and Burkitt lymphoma and (***) diffuse large B-cell lymphoma and plasmablastic lymphoma of the oral mucosa type. P values to S100+/IDCs between (\#) diffuse large B-cell lymphoma and Burkitt lymphoma, (\#\#) plasmablastic lymphoma of the oral mucosa type and Burkitt lymphoma and (\#\#\#) diffuse large B-cell lymphoma and plasmablastic lymphoma of the oral mucosa type

\begin{tabular}{|c|c|c|c|c|}
\hline & $\begin{array}{l}\text { Diffuse large } B- \\
\text { cell lymphoma } \\
\quad(\mathrm{N}=17)\end{array}$ & $\begin{array}{c}\text { Plasmablastic lymphoma } \\
\text { of the oral mucosa } \\
\text { type }(\mathrm{N}=11)\end{array}$ & $\begin{array}{l}\text { Burkitt lymphoma } \\
\qquad(\mathrm{N}=15)\end{array}$ & $P$ values \\
\hline $\begin{array}{l}\text { Caldesmon+/FDCs } \\
\left(\mu m^{2}\right)(\text { mean } \pm S D)\end{array}$ & $*, * \star \star 15.0 \pm 4.3$ & $\star *, * * \star 12.0 \pm 5.0$ & $*, * * 9.3 \pm 2.2$ & $\begin{array}{l}{ }^{*} p=0.0005 \\
{ }^{* *} p=0.37 \\
{ }^{* * *} p=0.09\end{array}$ \\
\hline $\begin{array}{l}\mathrm{S} 100+/ I D C s\left(\mathrm{~mm}^{2}\right) \\
(\mathrm{mean} \pm \mathrm{SD})\end{array}$ & $\#, \# \# 2.8 \pm 1.5$ & 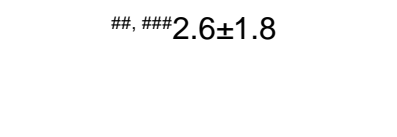 & $\#, \# 1.6 \pm 1.2$ & $\begin{array}{l}\# p=0.018 \\
{ }^{\#} p=0.22 \\
p=0.7\end{array}$ \\
\hline
\end{tabular}

was immunopositive in vessel blood walls distributed between neoplastic lymphoid cells. No cells immunopositive to CD1a were observed in the all oral lymphomas. S100+/ IDCs were present in all cases and were scattered amongst neoplastic lymphoid cells. S100+/IDCs were large cells, disclosing a round nucleus and irregular cytoplasm (Figure $1 \mathrm{H})$.

Mean values and standard deviation of the quantification of caldesmon+/FDCs and S100+/IDCs are presented in Table 1. BL had significantly statistical less caldesmon+/ FDCs and IDC/S100+ than DLBCL. There is not statistical difference of the caldesmon+/FDCs and S100+/IDCs quantification between BL and PBLOMT, and DLBCL and PBLOMT, respectively.

\section{DISCUSSION}

FDCs and IDCs are related to B or T and NK-cell diseases ${ }^{1,3,7,12,14,17,24}$. More frequently FDCs are evaluated in reactive follicles and follicular lymphomas because of microenvironmental similarity between reactive follicles and follicular lymphomas ${ }^{1,3,7,15,24}$. Oral lymphomas are almost exclusively B-cell neoplasm, presenting a diffuse pattern of growth ${ }^{10}$. Therefore, the finding of rare CD21+/CD35+/ FDCs is expected. Using antibodies anti-CD21 and antiCD35, FDCs were visualized in two cases of DLBCL as a sparse and disrupted meshwork in neoplastic pseudofollicular proliferation centers, as demonstrated by Maeda, et al. ${ }^{14}$ and Mori, et al. ${ }^{17}$ that evaluated FDCs in Bcell neoplasm with a diffuse pattern. Actually, the role of FDCs is to present antigens to B-cell ${ }^{9,21}$. In the process of the antigen-presenting, the activation of complement receptors $\mathrm{C} 3 \mathrm{~d}$ (detected by $\mathrm{CD} 21$ ) and $\mathrm{C} 3 \mathrm{~b}$ (detected by CD35) takes place in the FDCs ${ }^{19}$. Therefore, the detection of FDCs by CD21 and CD35 depends on their activation, which occurs in reactive follicles, neoplastic pseudofollicular proliferation centers or in neoplastic follicles of follicular lymphomas ${ }^{14,17,19}$.

Morphologically, MALT lymphomas present reactive follicles ${ }^{10}$. In the present study, CD21 and CD35 identified FDCs in the case of MALT lymphoma that exhibited reactive follicles. Bagdi, et al. ${ }^{1}$ also verified that stain for CD21, $\mathrm{CD} 23$ and CD35 revealed dense FDCs meshwork in reactive follicles of seven cases of primary salivary gland or gastric MALT lymphomas. In the present study, the two cases of MALT lymphomas were of the salivary gland type. So, in MALT lymphoma the immunolocalization of the FDCs by CD21 and CD35 is also dependent on the microenvironment organized by neoplastic or non-neoplastic lymphoid cells in the reactive follicles.

MCL typically present a loosely arranged, ill-defined and expanded meshwork of FDCs at the periphery of the neoplasm in nodular or diffuse pattern as demonstrated in the studies of Bagdi, et al. ${ }^{1}$ and Mori, et al. ${ }^{17}$. It was also observed this distribution of FDCs in the case current of MCL. This finding is important since this pattern of distribution of FDCs resembles that of the mantle zone of non-neoplastic lymphoid follicles. Also, the immunohistochemistry of FDCs in MCL is helpful to diagnosis of this disease ${ }^{1,17}$.

In T-cell and NK-cell neoplasm, the CD21+/CD35+/ FDCs are not frequently identified, as in our study ${ }^{1,15,24}$. However, angioimmunoblastic T-cell lymphoma presented a expanded meshwork of CD21+/CD23+/CD35+/FDCs. It has been suggested that these cells may be not real FDCs, but rather fibroblastic reticular cells showing overexpression of CD21, CD23 and CD35 $5^{10-13}$.

Immunolocalization of FDCs by caldesmon has not been widely evaluated. Tsunoda, et al. ${ }^{24}$ used caldesmon to evaluate neoplastic follicles of follicular lymphoma and verified a difference in FDCs immunoexpression in follicular lymphomas grade I, II and III. Caldesmon stained FDCs in all the studied oral lymphomas, and FDCs were visualized 
as a lacy pattern meshwork among neoplastic lymphocytes. Also, caldesmon immunoexpression was coincident with CD21 and CD35 immunoexpression. Thus, in the B-cell neoplasms (DLBCL, PBLOMT, BL, MALT lymphoma and MCL) evaluated, caldesmon+/FDCs might represent nonactive FDCs, since active FDCs are immunoexpressed in follicular microenvironment ${ }^{1,9,21}$. In the T-cell and NK-cell neoplasms (ETCL and PTCL) evaluated, caldesmon+/FDCs also may represent non-active FDCs or fibroblastic reticular cells with an overexpression of caldesmon. Tsunoda, et al. ${ }^{24}$ suggested that caldesmon on actin filaments, and extracellular matrix adhesion receptors on FDCs may be the main way whereby FDCs twine around extracellular fibers, contributing to the formation and maintenance of the meshwork structure. In accordance to Tsunoda, et al. ${ }^{24}$, may be that in oral B-cell, T-cell and NK-cell neoplasms caldesmon is also the major way of the formation and maintenance of the meshwork structure of FDCs or fibroblastic reticular cells overexpressing caldesmon.

IDCs were identified by the immunoexpression of S100 protein $^{8,9,22}$. In order to exclude the possibility of Langerhans cells, reactions to CD1a were performed in all oral lymphomas, and were negative in all of them. Thus, it can be asserted that in the present study the cells positive to S100 protein were IDCs, as Shinzato, et al. ${ }^{20}$ and Fonseca, et al. ${ }^{5}$ showed.

A few papers have evaluated S100+/IDCs in lymphomas $^{12}$. As IDCs are known as antigen-presenting cells to T-cells, they probably represent active cells in oral lymphomas, since a few non-neoplastic T-cells are always present in all B-cell neoplasm. Another possibility is that IDCs represent a casual feature in lymphomas due to a favorable microenvironment as also seen is non-neoplastic lymphoid tissue ${ }^{9,19}$.

Quantitative analysis of the DCs has never been performed before. Thus, this study represents the first one to perform a quantitative analysis of the DCs in lymphomas. Caldesmon and S100 protein were quantitatively analyzed because the immunoexpression was consistently present in all cases. It was observed that BL presented a lower statistically significant number of caldesmon+/FDCs and S100+/IDCs than DLBCL. This finding may be related to the fact that BL is a specific entity and presents a high proliferation rate, shown by the high mitotic counting, spontaneous cell death, and high counting (close to a 100\%) of Ki-67 positive cells ${ }^{10}$. It is well known that FDCs are related to B-cell proliferation ${ }^{8,9,22}$. Also, PBLOMT represent a subgroup of DLBCL that is more frequent in HIVpatients $^{4,10}$. PBLOMT may have the same state of cell proliferation than DLBCL. Meugé-Moraw, et al. ${ }^{16}$ evaluated reactive bone marrow biopsies and observed that HIVpatients did not present differences in FDCs immunoexpression. Therefore, cell proliferation in oral lymphomas may be related to the appropriated microenvironment to development of DCs.

\section{CONCLUSIONS}

The microenvironment determined by neoplastic lymphoid cells in oral lymphomas is responsible by the development and expression of dendritic cells types.

\section{ACKNOWLEDGMENTS}

This study was supported by the National Council for Scientific and Technological Development (CNPq, \#484974/2006-8, \#301490/2007-4) and by the State of São Paulo Research Foundation (FAPESP, \#01/06351-2). Dr. Mesquita, Dr. Araújo, Dr. Nunes and Dr. Sousa are research fellows of CNPq.

\section{REFERENCES}

1- Bagdi E, Krenacs L, Krenacs T, Miller K, Isaacson PG. Follicular dendritic cells in reactive and neoplastic lymphoid tissues: a reevaluation of staining patterns of CD21, CD23, and CD35 antibodies in paraffin sections after wet heat-induced epitope retrieval. Appl Immunohistochem Mol Morphol. 2001;9(2):117-24.

2- Bjercke S, Braathen G, Gaudernack G, Thorsby E. Relative efficiency of human Langerhans' cells and blood derived dendritic cells as antigenpresenting cells. Acta Derm Venereol. 1985;65(5):374-8.

3- Carbone A, Manconi R, Poletti A, Colombatti A, Tirelli U, Volpe R. S100 protein, fibronectin, and laminin immunostaining in lymphomas of follicular center cell origin. Cancer. 1986;58(10):2169-76.

4- Colomo L, Loong F, Rives S, Pittaluga S, Martinez A, Lopez-Guillermo A, et al. Diffuse large B-cell lymphomas with plasmablastic differentiation represent a heterogeneous group of disease entities. Am J Surg Pathol. 2004;28(6):736-47.

5- Fonseca R, Yamakawa M, Nakamura S, Van Heerde P, Miettinen M, Shek TW, et al. Follicular dendritic cell sarcoma and interdigitating reticulum cell sarcoma: a review. Am J Hematol. 1998; 59(2):161-7.

6- Gerdes J, Stein H, Mason DY, Ziegler A. Human dendritic reticulum cells of lymphoid follicles: their antigenic profile and their identification as multinucleated giant cells. Virchows Arch B Cell Pathol Incl Mol Pathol. 1985;42(2):161-71.

7-Gloghini A, Carbone A. The nonlymphoid microenvironment of reactive follicles and lymphomas of follicular origin as defined by immunohistology on paraffin-embedded tissues. Hum Pathol. 1993;24(1):67-6.

8- Imai Y, Yamakawa M, Kasajima T. The lymphocyte-dendritic cell system. Histol Histopathol. 1998;13(2):469-510.

9- Imai Y, Yamakawa M. Morphology, function and pathology of follicular dendritic cells. Pathol Int. 1996;46(11):807-33.

10- Jaffe ES, Harris NL, Stein H, Vardiman JW. World Health Organization classification of tumours: pathology and genetics of tumours of haematopoietic and lymphoid tissues. Lyon: IARC Press; 2001.

11- Jones D, Jorgensen JL, Shahsafaei A, Dorfman DM. Characteristic proliferations of reticular and dendritic cells in angioimmunoblastic lymphoma. Am J Surg Pathol. 1998;22(8):956-64.

12- Kornstein MJ, Bonner H, Gee B, Cohen HTR, Brooks JJ. Leu M1 and S100 in Hodgkin's disease and non-Hodgkin's lymphomas. Am J Clin Pathol. 1986;85(4):433-7. 
13- Leung CY, Ho FC, Srivastava G, Loke SL, Liu YT, Chan AC. Usefulness of follicular dendritic cell pattern in classification of peripheral T-cell lymphomas. Histopathology. 1993;23(5):433-7.

14- Maeda K, Matsuda M, Narabayashi M, Nagashia R, Degawa N, Imai Y. Follicular dendritic cells in malignant lymphomas-distribution, phenotypes \& ultrastructures. Adv Exp Med Biol. 1993;329(1):399-404.

15- Maeda K, Matsuda M, Suzuki H, Saitoh H. Immunohistochemical recognition of human follicular dendritic cells (FDCs) in routinely processed paraffin sections. J Histochem Cytochem. 2002;50(1):147586.

16- Meugé-Moraw C, Delacretaz F, Baur AS. Follicular dendritic cells in bone marrow lymphoproliferative diseases: an immunohistochemical study including a new paraffin-resistant monoclonal antibody, DR53. Histopathology. 1996;28(4):341-7.

17- Mori N, Oka K, Kojima M. DRC antigen expression in B-cell lymphomas. Am J Clin Pathol. 1998;89(4):488-92.

18- Raymond I, Al Saati T, Tkaczuk J, Chittal S, Delsol G. CNA.42, a new monoclonal antibody directed against a fixative-resistant antigen of follicular dendritic reticulum cells. Am J Pathol. 1997;151(6):1577-85.

19- Roitt I, Brostoff J, Males D. Immunology. London: Mosby; 1999.

20- Shinzato M, Shamoto M, Hosokawa S, Kaneko C, Osada A, Shimizu $\mathrm{M}$, et al. Differentiation of langerhans cells from interdigitating cells using CD1a and S-100 protein antibodies. Biotech Histochem. 1995;70(3):114-

21- Steinman RM. The dendritic cell system and its role in immunogenicity. Annu Rev Immunol. 1992;9(1):271-96.

22- Tew JG, Wu J, Qin D, Helm S, Burton GF, Szakal AK. Follicular dendritic cells and presentation of antigen and costimulatory signals to $\mathrm{B}$ cells. Immunol Rev. 1997;156(1):39-52.

23- Tew JG. Follicular dendritic cells and dendritic cell nomenclature. Adv Exp Med Biol. 1993;329(1):467-8.

24- Tsunoda T, Yamakawa M, Takahashi T. Differential expression of $\mathrm{Ca}(2+)$-binding proteins on follicular dendritic cells in non-neoplastic and neoplastic lymphoid follicles. Am J Pathol. 1999;155(3):805-14.

25- Turner RR, Wood GS, Beckstead JH, Colby TV, Horning SJ, Warnke PA. Histiocytic malignancies. Morphologic, immunologic, and enzymatic heterogeneity. Am J Surg Pathol. 1984;8(17):485-500. 